\title{
Praising the poor and blaming the rich: A panegyric reading of Luke 6:20-49 in Malawian context
}

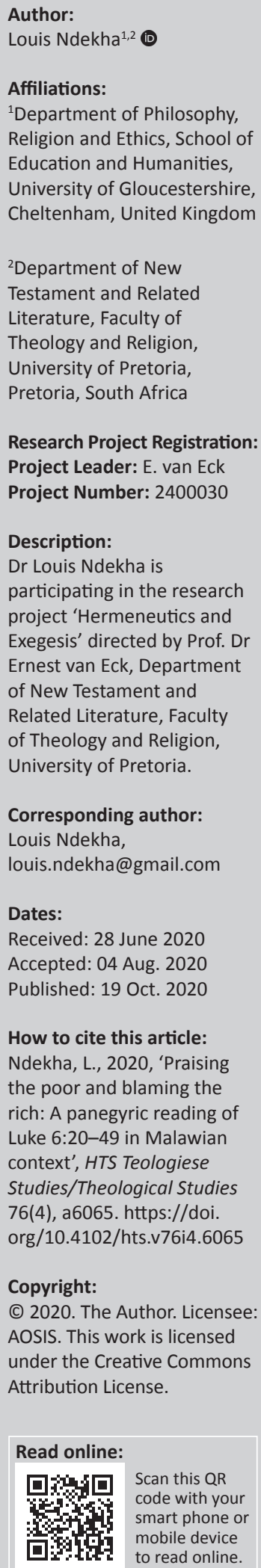

The article presented a panegyric reading of the Sermon on the Plain (Lk 6:20-49) in the Malawian context. It observed that, unlike its Matthean counterpart (Mt 5-7), the Sermon holds an insignificant place in African hermeneutics. Based on the Sermon's structure and content the article proposed the Greco-Roman panegyric, whose function was to inculcate commonly held values, as a framework for reading of the Sermon. It argued that when read in its original context as a Greco-Roman panegyric, the Sermon's radical stance on poverty and riches had significant implications for African and Malawian socio-economic realities. It brought into light the complicated relationships between the poor and rich both among Luke's original audience and the contemporary Malawian context. The panegyric reading of the Sermon also had a significant bearing on the application of the ubuntu philosophy in socioeconomic interrelationships in Malawi. The article posited that the socio-economic inequalities in Malawi caused by corrupt, cronyism and nepotism not only challenge the majority Christian status of the nation but also the foundations of the African values of ubuntu. As a panegyric, the Sermon therefore challenges Malawian Christians to rethink their values and the relationship between the rich and the poor.

Contribution: The article provides a new perspective to the interpretation of the Sermon on the Plain in African context. Against the background of its apparent neglect in African hermeneutics, the article underscores the relevance of the Sermon on the Plain to socioeconomic discourse in Malawi in particular and Africa in general.

Keywords: Luke; Sermon on the Plain; Panegyrics; Praise and blame; Poverty; Riches; Community; African contextual hermeneutics; Malawi.

\section{Introduction}

The Sermon on the Plain ${ }^{1}$ (Lk 6:20-49) has historically occupied an insignificant place in African biblical hermeneutics. One possible reason for its apparent irrelevance is the way the Sermon's makarisms ${ }^{2}$ and woes put in the spotlight the relationship between the rich and the poor. This leftist stance creates a potential hermeneutical complexity that baffles interpreters. As a result, even in a majority Christian nation like Malawi, one rarely hears a homily on the Sermon, let alone recitals of its makarisms or woes. Instead, Matthew's Sermon on the Mount (Mt chapters 5-7) remains the dominant text in the study of Jesus' inaugural sermon and its makarisms are common parlance for an average Christian.

With the growing influence of the prosperity gospel in Africa, it is likely that the Sermon's praise of the poor and invective on the rich will continue to make its place in Malawian hermeneutics untenable. However, despite this apparent neglect, when it is read from the perspective of Luke's Greco-Roman audience, ${ }^{3}$ where praise and blame were useful tools for social control, the Sermon's leftist stance and the issues it raises have a strong affinity with African socioeconomic realities.

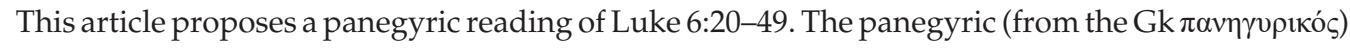
was a formal public speech, usually in verse, given in praise of a person or any phenomena. The original panegyrics, whose function was to enforce commonly held community values, were

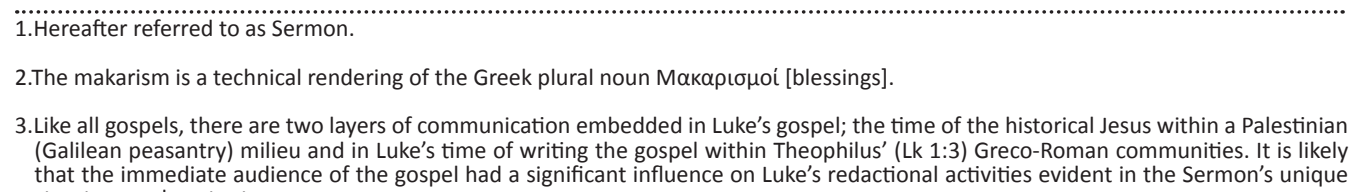
structure and content. 
speeches delivered at public events in ancient Athens. During the Roman empire the panegyric was associated with eulogy for rulers.

The proposal for a panegyric reading of the Sermon is based on the understanding that a significant trait of Greco-Roman panegyrics was their juxtaposition of praise and blame combined with exhortation. An observation of the Sermon's general structure of makarisms and woes (Lk 6:20-26) followed by exhortation (Lk 6:27-49) reveals its significant resonance with Greco-Roman panegyrics. Despite the growing interest in the relationship between Luke and Greco-Roman literature in recent studies, no study has so far examined the Third Gospel or the Sermon from a panegyric perspective. The article argues that the Sermon, read as a panegyric, has implications for the Malawian context. The socioeconomic inequalities between the rich and the poor in the country caused by corruption, nepotism and inequality, pose a challenge to the time-honoured African values of ubuntu, [humanity to others]. These negative social factors not only challenge the country's moniker as 'the warm heart of Africa', but also its majority Christian status. Undeniably, socioeconomic inequality is not just endemic to Malawi; it is a worldwide phenomenon. It signifies the state of brokenness that characterises the human condition. Yet, in a context like Malawi where the Bible has a significant influence on morality and ethics, the Sermon's radical approach to poverty and riches offers Christians the opportunity to rethink their understanding of community and the values that undergird their conception of power, privileges and interpersonal relationships.

In using the panegyric framework for the interpretation of the Sermon, the article focuses on the similarities between the Sermon and Greco-Roman panegyrics and how the function of the latter sheds light on the meaning and function of the Sermon within its original context and its implications for the Malawian context. The application of the reading of the Sermon to the Malawian setting is, however, made within the wider context of the African ubuntu philosophy with its emphasis on the importance of community in the realisation of individual potential.

The article has three sections. The first section 'Makarisms and woes and praise and blame in Greco-Roman context' analyses the relationship between praise and blame and makarisms and woes. The second section 'Greco-Roman panegyrics in context' examines the function of panegyrics in Greco-Roman context. Finally, it presents a panegyric reading of the Sermon against the conundrum of socioeconomic inequalities in Malawi. Through this approach the article contributes to the development of contextual biblical interpretation in Africa.

\section{Makarisms and woes and praise and blame in Greco-Roman context}

One of the critical issues in proposing a panegyric reading of Luke 6:20-49 is to establish the relationship between the
Sermon's makarisms and woes and the Greco-Roman panegyric. This relationship is essential for identifying parallels between the praise and blame of the panegyrics and the Lucan makarisms and woes (Lk 6:20-26) and the Sermon as a whole. In the first place, it is crucial to present the meaning and context of makarisms and woes. Hornblower and Spawforth (1996:914) indicated that in their original context, makarisms were a form of congratulation or compliment for good behaviour. They extolled the good fortunes of a person or exalted the person for the good fortune that they have had (Fitzmeyer 1981:632). Bovon (2002:221) also argued that in cultic contexts, they expressed the praise of those who walked in the ways of God. On the

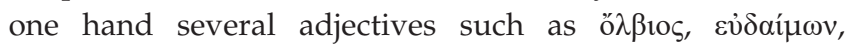

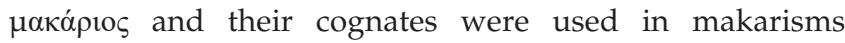
construction. The corresponding Latin adjectives were felix, beatus and fortunatus. On the other hand, the Greek ovoi, woe or its Latin equivalent, the vae or hue were the indeclinable interjections used in the woe construction (eds. Danker et al. 2000:734; Morwood 1994:182). The ovaí represented the antithesis of happiness and signified the experience of Greek какí [badness], which had the sense of ill-fatedness and misery (eds. Danker et al. 2000:500). In addition, the woe was measured in terms of quality as the opposite of $\alpha \rho \varepsilon \tau \eta$, [excellence], and, therefore, associated with cowardice, sloth, moral badness, wickedness and vice (Liddell, Scott \& Jones 2020).

The above analysis of makarisms and woes places them within the context of the honour and shame which were the normative values in the Greco-Roman world. Honour involves the worth, value, prestige and reputation which an individual claims and which is acknowledged by others (cf. Malina 2001:30; Neyrey 1998:15). The general cultural quest for honour gave expression to the Greco-Roman competitive spirit wherein individuals were driven to win and be called

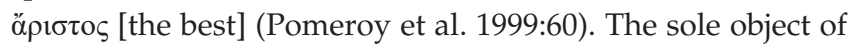
competing and striving was to win honour, which was the public recognition of one's skills or achievement (Pomeroy et al. 1999:60). The above understanding of the context of makarisms and woes also agrees with Hanson's (1996:81-111) observation that makarisms and woes belong to a word-field and value system of honour and shame. Hanson, therefore, translated Matthews's $\mu \alpha \kappa \alpha \rho$ ṕs and ov̉aí as 'how honourable' or 'how shameful' reflecting the honour and shame culture to which they correspond. Bovon (2002:222) corroborated Hanson's observation as he argued that the setting of the makarisms was the family, with its happy occurrences and the school in which the happiness of the diligent student was praised. Thus, according to Hanson on the one hand, the makarisms constituted the affirmation of values the community wished to validate. On the other hand, the woes' sense of misery, wretchedness and moral badness (cf. Liddell et al. 2020) demonstrate the accusatory and shameful tone every Greco-Roman male attempted to avoid. The above observations provide a plausible link between makarisms and woes and honour and shame, respectively. 
Like the makarisms and woes, the language of praise and blame, which was integral to panegyrics, belonged to the same word-field of honour and shame. The paradigm was intricately connected to the competitive spirit of the GrecoRoman culture and served as the vehicle through which honour and shame were exchanged (Kurke 1991:93). It is said that in striving to outdo each other, the motto was 'anything you can do, I can do better' (Fox 2005:68). Leslie Kurke demonstrates that even giving, receiving and repaying were understood and practised within the context of challenge and riposte. The one who received a gift or a challenge was obligated to make a return that was equal to or superior to this original gift or challenge (Kurke 1991:82). Failure to return an equal or superior gift/response resulted in a loss of honour. In this context, through the language of praise and blame the community expressed value judgement on certain persons and their actions. Neyrey (1998:71) argued that this was done by use of the correlative pair of words: praise and

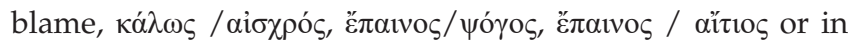
the Latin laus/vituperatio.

An examination of Greco-Roman literature also reveals that makarisms and woes had their context in praise and blame, respectively. For example, in the context of a victory ode Pindar would declare to his victor 'blessed are you, who have, even after great hardship, a memorial of the best words' (Pindar, Pyth. 5.60). ${ }^{4}$ To achieve victory and claim the honour of such praise represented the highest state of achievement to which any Greek male aspired. The makarism also potentially suggests that those who were defeated in the games experienced the opposite of honour: shame and its resulting loss of face. Similarly, in the Hymn to Mother Earth, the praise context of the makarism is also apparent. The narrator says: 'blessed is the man whom you (the gods) delight in honouring' (Hom. Hym. 30.7-8). The context of the above makarism is a praise of the goddess' (Mother Earth) generosity. It captures the implications of this generosity on those whom the goddess favours. The catalogue of good things that accrue to those favoured by the gods, such as riches and a happy life (Hom. Hym. 30. 9-15), reflects the praiseworthy aspects of Greco-Roman honour.

Inversely, concerning the woe, Epictetus, a first-century stoic philosopher, provides a typical Greco-Roman expression of shame and its corresponding blame. In his Diatribai (Dissertationes) 3:19 he declares 'woe unto me for my child, for my brother, for my father'. In the woe, Epictetus

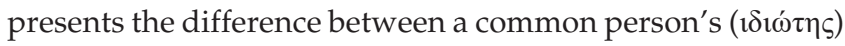
and a philosopher's conception of honour and shame. A common person thinks his honour can be compromised by his kin whilst the philosopher believes he is responsible for his honour and shame. Here, Epictetus not only provides the rare evidence for the use of the woe formula in Greek social conversation, but also highlights the pervasive nature of the Greco-Roman values of honour and shame, and how, in several instances, makarisms and woes in the form of praise and blame facilitated the exchange of these normative values. Amongst the gospels, Luke has the greatest number of makarisms and woes, whose contexts are also praise and blame (see Lk 1:45; 6:20-22; 7:23; 10:23; 11:27-28; 12:37-38; $12: 43 ; 14: 14-15 ; 23: 29)$. For example, the makarism 'Blessed is the womb that bore you and the breasts at which you nursed' (Lk 11:27) demonstrates how, awestruck by Jesus' dramatic casting out of a mute demon and his resulting discourse on Beelzebub, the woman burst into praise (v.14). ${ }^{5}$ Similarly, of the 32 occurrences of the woe formula in the New Testament Luke has 15, whose context is blame (Lk 6:24-26;10:13; 11:42-52; 17:1; 21:23; 22:22). For example, the woes in Luke 11:42-52 are set in the context of Jesus' reproach of the Pharisees' external religiosity, thus demonstrating the relationship between the woe and blame.

\section{Greco-Roman panegyrics in context}

As speeches of praise panegyrics were important features of Panhellenic festivals or festivals for single cities. ${ }^{6}$ Poetic panegyrics such as the victory odes of Pindar, Bacchylides and Simonides went far back into the history and culture of the Greek societies (Gallia 2012:44; Miller 2018:21-41; Pernot 2014:1). They represented the celebration of excellence in Greek communities. Prose panegyrics, whose emphasis was the concord between citizens of the polis or between Greek cities, ${ }^{7}$ usually aimed to stir the citizens to emulate the glorious deeds of their ancestors (Chrisholm 1911:676-677). The emphasis on concord reflected the conflicting visions amongst the Greeks both in the polis and at Panhellenic level and therefore aimed at encouraging friendliness and discouraging hostile feelings amongst Greeks from different poleis (Nightingale 1995:97). Thus, the panegyrics acted as 'carriers of social memory' of what was honourable in the community (Steinbock 2011:284). Moreover, as Roche (2011:6-7) argued, during the Roman imperial period, the panegyric praise acted as admonitory guidance to both the emperor and new senators. According to him, it was usually given by senior senators and represented an eminent senators' vision of an ideal emperor and the values a newly ennobled senators were to espouse.

In terms of genre, the panegyric belongs to epideictic rhetoric. As an epideictic, it has its audience in the observer $(\theta \varepsilon \omega \rho \operatorname{s}) .{ }^{8}$ Its subject matter is praise and blame and its telos is the honourable and the shameful (Nightingale 1995:94). The panegyric came in different forms: the time-honoured victory ode, the funeral oration, the festival speech and the eulogy for rulers. At the heart of the function of the

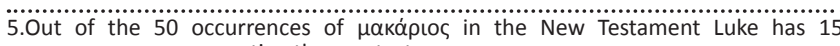
appearances, representing the greatest occurrence.

6.For example in his Panegyricus, which was addressed to all Greeks, Isocrates combines an exhortation to the Greeks to unite under the leadership of Athen against the common Persian enemies, and invective against discordant and hostile Greek cities such as Sparta. Similarly, in his Panathenaicus, in which, although Greek cities such as Sparta. Similarly, in his Panathenaicus, in which, although the censure of the Spartans. See Nightingale (1995:97).

7.Lysias, Oly. Or., 33.4; Xenophon, 14.4.15-16; Isocrates, Paneg., 4.3.

8.The word $\theta \varepsilon \omega \rho$ ó could mean emissary, spectator or one present at a festival (LSJ at Perseus 2020). 
panegyric in a community context was the reinforcement of commonly held values. For example, as De Bouvre (2012:275) demonstrated, in pouring extreme honour upon the victors of the games, the praise odes and the Hellenistic festive community presented the concept of victory as a key summarising symbol of Hellenic ethnicity. Thus, praise highlighted the values that the community expected of its members and therefore inspired others to crave for honour at par with or beyond that of the victors (Kurke 1991:6). Beyond the victory odes, Burke (1969:127-317) suggested that a significant function of epideictic speeches within a ritual context was to achieve symbolic transcendence of the sense of division amongst men. Burke's suggestion implies that division in the community provides the context for the community function of praise and blame. In a Greek context, such division could either be factional, as Lysia argues or neglect of the vulnerable members of the community, as Isocrates and Democritus allege (Lysias, Olym. Ora., 33.4; Democritus, Frag. 250; Isocrates, Areop. 7.83). In an African context this division can be understood in terms the tribalism and the cronyism that leads to socio-economic inequalities.

The panegyric represented the most pronounced community use of praise and blame in classical antiquity. The panegyrics of Gorgias, Lysias and Isocrates provide models of community oratory in the Greek context. The distinctive feature of a panegyric was its combination of praise and blame with the rhetoric of advice found in the deliberative oratory (Nightingale 1995:97). For example, in his Panegyricus (Or.4), which was addressed to all Greeks, Isocrates combines an exhortation to the Greeks to unite under the leadership of Athens against the 'common enemies, the Persians' and invective against discordant and hostile Greek cities such as Sparta. Similarly, in his Panathenaicus (Or.12) in which, although addressed to Athens only, Isocrates devoted himself to the praise of Athenians and the censure of the Spartans. Another unique dimension of the panegyric is that their audience and context determined both the content and orientation of speeches. As Nightingale noted, the orators tailored their speeches to the different audiences at the different kinds of festivals (Nightingale 1995:89).

The above influence of the audience on the content of panegyrics signifies the epideictic preoccupation with the present. By dealing with the present, as Beale (1978:226) argued, epideictic performances participate in the reality to which they refer. They define their community's present circumstances, values and experiences (Villadsen 2008:32). Sullivan (1999:53) further added that by praising people, actions and ideals that embody a culture's concept of virtue, the epideictic rhetor builds an image of 'who we are'. Conversely, by blaming actions and ideas, the rhetor creates an image of 'what we are not'. Thus, according to Sullivan, the image of orthodoxy is a concrete display of what it takes to be an insider, whereas the image of heterodoxy is a display of the excluded other. It can be observed that panegyrics' emphasis on the inculcation of commonly agreed community values has significant resemblance with the African philosophy of $u b u n t u$. Rooted in the importance of community, ubuntu is encapsulated in the common adage 'Iam because we are'. According to Dreyer (2015:196), three characteristics define ubuntu ethics: (1) the responsibility for togetherness, (2) the relationship between community personal identity and true humanity and (3) the importance of the values of generosity, hospitality, friendliness, compassion and solidarity. In Malawi the concept is referred to as umunthu, 'being human' (Musopole 2018:18). It entails displaying a character expected of an individual in the community. The importance of community, generosity and compassion is also a major thematic thrust of Luke's writings (Lk 10:25-35; 14:15-24; Ac 2:46-47; 4:34).

The above function of panegyrics provides a framework for understanding the meaning of the Sermon both in Luke's original setting and any context in which it is read. The relationship between the Sermon and panegyrics remains unexplored. Nevertheless, Kennedy (1984:45) classified Luke 6:27-49 as deliberative, because, in it, Jesus gives advice. He also recognises the makarisms and woes (Lk 6:20-26) as epideictic. Although Kennedy does not recognise the implications of his classification of the genres in the Sermon, the combination of the two rhetorical genres confirms its affinity with panegyrics (cf. Nightingale 1995:97). Furthermore, the Sermon's literary structure and content demonstrate its affinity with the panegyrics. Firstly, the structure of events from Luke 6:13-17 has panegyric import. In Luke 6:13 Jesus named his disciples and appointed his apostles on the Mountain. He thereafter led them in a procession downhill. The entourage later merged with the assembly of people from different ethnicities and regions of Palestine at the level place in Luke 6:17 where Jesus addressed them. The whole process echoes a Greek Panhellenic convocation. As Isocrates argued, having proclaimed a truce and resolved their quarrels, the Greeks came together and through panegyrics, were reminded of the kinship and the need to be united and be kind to each other (Isocrates, Paneg. 4.43). Secondly, whilst the makarisms and woes are specifically directed at the disciples (Lk 6:20-26) the fact that demands of the Sermon are addressed to all who would hear (Lk 6:27, 47) provides a community dimension to the Sermon (cf. Brown 1997:80). Thirdly, the Sermon's use of the present tense enhanced by the adverb võv (Lk 6:21, 25) echoes the panegyric preoccupation with present community issues. All these suggest that, like a panegyric, the Sermon's content was defined by the present circumstances of its primary audience.

The circumstances of the Sermon's audience are partly captured in the purpose of the Gospel. One of the reasons Luke wrote his gospel was for Theophilus and his fellow converts to know the certainty ( $\dot{\alpha} \sigma \varphi \alpha \dot{\lambda} \varepsilon 1 \alpha)$ of what they had been taught (Lk 1:4). From the Gospel's preoccupation with interpersonal issues, especially between the rich and the poor, one aspect of this $\dot{\alpha} \sigma \varphi \alpha \dot{\lambda} \varepsilon 1 \alpha$ was probably to help Theophilus understand the implications of Jesus' ethical and practical directives on interpersonal relationships 
(Topel 2001:7). This purpose is apparent in both the initial Nazareth proclamation(Lk4:16-30) and Luke's preoccupation with generosity to the poor across the gospel (Lk 10:29-37; 15:11-32; 19:1-10). This demonstrates that for Luke, whilst salvation had its basis in God's relationship with the individual, the expression of this relationship is found in concrete everyday interpersonal encounters in the community.

\section{Reading the Lukan text in a Malawian context}

The relevance of contextual biblical analysis in developing an African theology is documented in research (cf. LobaMkole 2008:1349; Mbengu 2011:4; Van Eck 2006:685). Three characteristics of African contextual biblical analysis underpin the thrust of this article: (1) its focus on the world of the text and that of the audience, (2) its creation of a dialogue between the text and the African context and (3) its attempts to solve the various problems rampant in African contexts through the process of appropriation (Mbengu 2011:4). In keeping with the above hermeneutical framework, this reading of the Sermon is made in the Malawian context, a Southern African country with a population of 18 million people. It has a GDP per capita of $\$ 370.7$ (IMF 2019). The country's resource structure reveals extreme inequalities. For example, a recent survey showed that the wealthiest $10 \%$ in the country spends 34 times more than the poorest (Mussa \& Masanjala 2015). This statistic suggests that out of the total population of 18 million, 1.8 million people have the largest share of the national wealth. This economic inequality is evident in many areas of public life. For example, food security is one of the biggest challenges in Malawi. Over $80 \%$ of the population is unable to produce enough food to last until the next harvest. The result is widespread malnutrition, stunted growth and high child mortality rate. A recent UNICEF report showed that only $8 \%$ of children between the ages of 6 and 23 months meet the minimum acceptable diet (UNICEF 2019). Yet, a third of the country's space comprises a vast water body and, therefore, capable of irrigation for food security, where political will and concern for the majority of poor existed. In education, inadequate infrastructure and low levels of resource provision constitute a significant challenge (Chimombo 2009:1). The scenario often leads to high dropout rates, especially amongst girls, resulting in early marriages and the vicious cycle of poverty and health problems across the population (Bisani 2019). Meanwhile, the children of elite, using national resources, have access to the best education in the land and abroad. The provision of health services is also amongst the worst in the world, with the majority unable to access basic medication whilst the rich few have access to the best health service both local and international (Zere et al. 2007:1-13).

Central to the inequality in the country are the loop holes in the public finance management system and corruption in public services delivery (Mussa \& Masanjala 2015:8). Fuelled by nepotism and tribalism, corruption enables only those connected to the political system or those able to pay their way into the system to benefit from public resources. Coincidentally, in a country where over $80 \%$ of the population are professing to be Christians (NSO 2008), socio-economic inequality also applies to the faith community. The growing number of rich self-styled ministers whose lifestyle is paid for by religiously naive poor Christians and the magnificent multimillion-dollar cathedrals and auditoriums mushrooming across the country are a big contrast to the widespread hunger and poverty of the average Malawian. The above scenario indicates serious fault lines in the country's socio-economic structure and a challenge to the sense of the nation as a community. The scenario demonstrates a failure to live out the ubuntu philosophy and its ethical values of generosity, hospitality, friendliness, compassion and solidarity (cf. Dreyer 2015:196).

From its opening statement in Luke 6:20, the controlling narrative agents in the Sermon are poverty, riches and the Kingdom of God. The rest of the corresponding word pairs of Luke 6:20-26 'hungry and weeping' and 'filled and laughing' only particularise the experience of poverty and riches (Coleman 2017:48-67). Poverty and riches serve two functions in the Sermon. Firstly, in epideictic terms, they highlight the economic and social contradictions in the communities of Lukan churches and by implication, the Malawian context. Secondly, as a corollary, they help to create a rhetorical

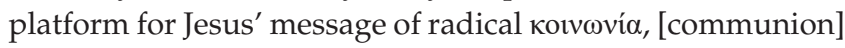
between the rich and the poor. Similarly, the Kingdom of God, of which the recipients were the poor (Lk 6:20), serves two purposes. It provides a providential dimension to the idea of the community of Christ-followers. Thirdly, beyond its eschatological implications, it challenged the present status of socio-economic division within the community and offered the possibility for a new understanding of kinship and communion between the rich and poor.

In the first section of the Sermon (Lk 6:20-24), Jesus first addresses the disciples as those who are poor, hungry, mourning and ostracised or as rich, filled, laughing and praised (Lk 6:25-26). Luke's preference to start with the praise of the poor suggests that, like the Malawian context, the poor constituted the majority of Jesus' audience. ${ }^{9}$ It is also likely that the poor were at the receiving end of socioeconomic ostracism. In the New Testament world, hunger, mourning and ostracism reflected the experience of $\pi \tau \omega \chi \varepsilon i ́ \alpha$ [destitution] (Tannehill 1996:115). ${ }^{10}$ On the one hand, it was associated with powerlessness, dependence on others and vulnerability. On the other hand,being rich was synonymous with being powerful, secure, independent and locked in an exploitative relationship with the poor (Van Eck 2009:2). Therefore, by juxtaposing poverty and riches, Luke places the contradictory values of power and powerlessness in the Greco-Roman world into sharp focus. In this way, he highlighted the social

9.Jehne (2011:111) argued that in Greco-Roman oratory praise often went towards the majority in the audience.

10.See also Euripides, Helen, 790, where Menelaus, upon his return from Troy under

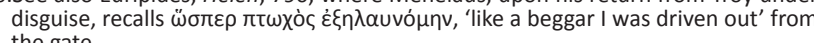
the gate. 
questions amongst his primary audience and prophetically, by implication, of any community in any time, like the Malawian context, where socio-economic inequalities exist.

Jesus' praise of the destitute had pedagogical import for both Luke's churches and by implication the Malawian context. Firstly, the praise reinvigorated those like Barnabas (Ac 4:36)

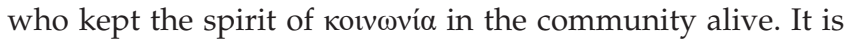
also likely that unlike most rich people (Lk 12:16-12; 18:1827), the poor would have found it easier to share with others in the community (Lk 10:25-37; Lk 16:1-13; Lk 21:1-4). To the rich, the praise of the poor was also both an encouragement and a challenge to their conception of riches and poverty and therefore, a call to a renewed relationship between the rich and the poor. By praising the unpraisable and bestowing honour on the destitute with its promises and invective on the rich with its misfortunes, respectively, (Lk 6:24-26), Luke also demonstrates that the rich are not eternally better than the poor. It was only a matter of time before the destitute enjoyed the same privileges as the rich (16:19-31). ${ }^{11}$ In this case, as Sheard (1996:770) argued, praise reinforced the norms of public morality that made the act of praising akin to asking for a course of action.

Furthermore, in declaring blessings upon the poor Jesus also questioned the propriety and, therefore, the legitimacy of the entire system of social stratification in Hellenistic cities and relativised what most people hold as advantages and disadvantages (Byrne 2002:77; Esler 1987:189). Read contextually, the makarisms and woes also put into question the entire political and socio-economic organisation of Malawi where the quest for wealth and prestige by a few puts the majority at a disadvantage. In declaring the poor blessed, Jesus emphasises that human dignity regardless of social status should be the defining factor in social relations. When national budget allocations indicate billions of dollars to state residences and executive allowances against the backdrop of hungry masses, poorly equipped hospitals and shabby schools, it is an affront on human dignity and a contradiction to the spirit of Jesus' mission. Such a situation is contrary to the spirit of ubuntu in which the spirit of generosity, compassion and concern others is a characteristic trait.

It is also important to note that Jesus does not blame the rich because they are rich (vv. 24-26). It is instead because of the toxic values associated with riches to which most of the wealthy fall prey. Like anywhere, including Malawi, the quest for personal status and honour often drive the rich into self-preoccupation that usually render them incapable of being considerate over the poor (Lk 16:20; Lk 18:22-23). In the makarisms and woes, Jesus calls upon the rich to adopt the three values associated with destitution: powerlessness, dependence and vulnerability. These values underscore the role of interdependence between the rich and poor in realising community aspirations. For Luke, the rich can begin to work towards the realisation of these value by inviting the poor for 11.The promises accorded the poor, satisfaction, laughter and rewards echo Lucian's
conception of the fate of the poor and the rich in the afterlife when everyone will be equal. See Lucian, Mortuorum Dialogue, 1.4 . table fellowship (Lk 14:12-24), trade justice (Lk 16:1-9), giving part of one's riches to the poor (Lk 19:1-10) or selling all, giving the money away and following Jesus (Lk 18:22). In the Malawian context this means the rich and powerful both in church and society are practically living the values of ubuntu and therefore ensuring that national resources benefit not just a few but everyone in the community.

The reference to the Kingdom of God (Lk 6:20) as the heritage of the poor also had a community-building dimension for both Luke's audience and the Malawian context. The Kingdom of God as an overarching cosmos is a characteristic Lukan motif. The concept is mentioned 44 times in Luke and 52 times across Luke-Acts. At a basic level, the promise of the Kingdom of God to the poor and its corresponding attributes of satisfaction, laughter (Lk 6:20-24) and rewards (Lk 6:23) underscore the fact that it is possible to be satisfied, to laugh and be accepted without being rich. This understanding provides a sobering reminder of the superficiality of the endless quest for wealth that characterises modern business practices. Furthermore, the reference to the Kingdom and its privileges is also a social indictment of the rich who neglect their responsibility for the poor. In the context of systemic community failure to care for the vulnerable, the Kingdom becomes an alternative imagined place where the poor find support (Q 10:2-10; Q 11:11-13; Q 12:22-31; Lk 8:13; Moxnes 2003:116-117).

Whereas the ultimate realisation of the blessings of the poor would be in the eschaton, Luke's depiction of Jesus' magnanimity demonstrates his intention to project an alternative community for both the rich and the poor. Across the gospel, Luke uses the Kingdom of God as a metaphor for hospitality (Moxnes 2003:114; Verheyden 1999:974). Jesus' description of non-Jewish generosity (Lk 10:25-37), his magnanimity to the masses (Lk 9:1-17), his association with the rich outcasts (Lk 19:1-10) and sinful ( $\left.\dot{\alpha} \mu \alpha \rho \tau \omega \lambda \mathrm{o}_{\varsigma}\right)$ woman (Lk 7:36) demonstrated his conception of the realised aspects of the Kingdom which his disciples and those after them should emulate. In this way, Luke underscores the importance of an inclusive form of social relations that transcend the exclusivist and legalistic Jewish purity system that left many outside the realm of official religion (Elliott 1991:102-108). Therefore, Jesus' declaration that the hungry will be fed and the mourning will laugh (vv.21) envisages the practical outworking of the possibilities created by the realised aspects of the Kingdom for God's people. As understood from a Malawian context, it suggests that in a country where the majority are Christians, social relations should be characterised by the generosity associated with ubuntu. It implies that those in privileged positions, both in church and society, and who have access to and responsibility for the distribution of social goods and resources, have an obligation to ensure the welfare of the less privileged. For Luke, those who indulge in the excessive acquisition of wealth at the expense of the poor have received their portion in this life (Lk 6:24). To such, the reversal of fortunes demonstrated across the gospel (Lk 1:51-53; 16:9-12, 19-31) will be their lot. 
In Luke 6:27-49 Jesus offers the possibility of achieving the realised aspects of the Kingdom for both the rich and poor. By beginning with the love of the other (v. 27), Jesus sets out the parameters on which an inclusive community between the rich and the poor can be built. He demonstrates that the love of the other was the foundation for building a socially inclusive community within the Lucan churches and any other community. In order to achieve this community, Jesus prescribes remedies that were utterly inconsistent with the prevailing Greco-Roman morality. The cultural conventions of the time, like the ethnocentrism, cronyism and nepotism that permeate Malawian society, prescribed the philosophy of helping one's friends and harming one's enemies. ${ }^{12}$ Jesus' ethics, however, reversed this conception of community. In verses 27-49 he overturns the norm of the love of family and friend - do harm to enemies by erasing the boundary between family and stranger (Oakman 2014:121). ${ }^{13}$ In the new community the strangers or the socially different others are now the fictive kin, created out of their common calling as disciples of Jesus. In the Malawian context, they constitute the people from the other tribes and those socially and economically different. They constitute the majority of poor whose votes are more important than their humanity after elections. In a church context, the other constitute the nonclergy, the laity who constitute the body of Christ and those on whose behalf donations are requested from abroad but who never get to benefit from the same.

The Sermon therefore called upon the community of Christ-followers to be counter-cultural to its Greco-Roman context where kinship and reciprocity determined social relationships. Instead, they are to reflect the standards of the Kingdom. The new lifestyle would result in a community, as imagined by Plutarch's Cleomenes in Sparta, ${ }^{14}$ where there would be neither destitution nor extravagant riches. The realisation of this vision would, however, require model leadership of social inclusion by those who know Jesus. In the Malawian context such a model leadership would start with the church leaders demonstrating the values of $u b u n t u$ and in the process being able to influence the civic leadership of the nation. Failure to model that life would result in the blind leading the blind (Lk 6:39). Such a community would not reflect the Kingdom of God like a tree producing strange fruit (Lk 6:44-45). Furthermore, failure to adhere to the values propounded in the Sermon would be like building a community (a house) on the sand, with its disastrous consequences (Lk 6:46-49). Conversely, to heed Jesus' words implies grounding their building (their community) on Jesus'

12.See Blundeli (1989), Isocrates (Paneg. 1.26), and Euripides (EI 66).

13.The word k̇xӨpóৎ (Lk 6:27), although generally translated as 'enemy', lexically refers to hostilities between individuals who know each other (Danker et al.

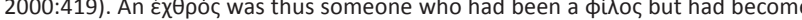

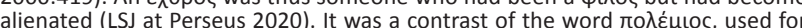
conflict concerning an external enemy (cf. Aeschines, Ctes. 3.172). Thus, غ́x日pó conflict concerning an external enemy (cf. Aeschines, Ctes. 3.172). Thus, $\varepsilon \chi \theta \rho o$ was synomous with the term $\delta \cup \sigma \mu \varepsilon v \eta$ s or 'one who has long been alienated and
refuses to be reconciled'. (LSJ, at Perseus 2020).

14.Plutarch (Cleom. 10.1-4) reports that when Cleomenes became King of Sparta in $241 \mathrm{BCE}$, he sent 80 wealthy senators into exile. He wanted to rid Sparta of luxury and extravagance, debts and usury and evils older than those namely, poverty and wealth. exhortation with all that implied: an inclusive community in which resources are equitably shared, and no one lacked anything (Ac 4:34). It implies building a community on the solid foundation of unity, fellowship and the love of the other. In the Malawian context, it entails living as a community where the values of $u b u n t u$ are the characteristic ethos.

\section{Conclusion}

The article has demonstrated the relevance of the Sermon to the Malawian context. Its leftist stance illustrates Jesus' commitment to the principles of social equality and egalitarianism. It underscores the fact that when economic activities both in society and the church are oblivious to the plight of the poor, it defeats the community dimension of Christian fellowship. The Sermon therefore provides a framework through which Malawian Christians and Africans in general, can reflect on the economic and social contradictions in the community and the need to deal with them. It challenges politicians to restructure government economic priorities and ensure that budgetary allocations do not benefit a few but demonstrate the spirit of generosity and consideration of others reflective of the spirit of ubuntu. It also challenges the rich to rethink their socio-economic priorities; that excessive acquisition at the expense of the poor is an affront not only on human beings made in the image of God but is also contrary to the spirit of ubuntu that defines them as Africans. Lastly, the Sermon challenges the church to rethink its internal financial arrangements that concentrate resources towards a few individuals and infrastructural development programmes that seem oblivious to the socio-economic realities of its immediate communities.

\section{Acknowledgements Competing interests}

The author declares that he has no financial or personal relationships that may have inappropriately influenced him in writing this research article.

\section{Author's contribution}

L.N. is the sole author of this research article.

\section{Ethical considerations}

This article followed all ethical standards for research without direct contact with human or animal subjects.

\section{Funding information}

This research received no specific grant from any funding agency in the public, commercial or not-for-profit sectors.

\section{Data availability}

Data sharing is not applicable to this article as no new data were created or analysed in this study. 


\section{Disclaimer}

The views and opinions expressed in this article are those of the author and do not necessarily reflect the official policy or position of any affiliated agency of the author.

\section{References}

Beale, W.H., 1978, 'Rhetorical performative discourse: A new theory of epideictic', Philosophy \& Rhetoric 11(4), 221-246.

Bisani, L., 2019, 'Malawi education: Poverty major cause for school dropouts' Malawi24 viewed 12 July 2020, from https://malawi24.com/2019/01/02/ malawi-education-poverty-major-cause-for-school-dropout/.

Bovon, F., 2002, Luke 1, Fortress Press, Minneapolis, MN.

Brown, E.R., 1997, Introduction to the New Testament, Double Day, New York, NY. Burke, K., 1969, A grammar of motives, University of California Press, Berkeley, CA.

Byrne, B., 2000, The hospitality of God, Liturgical Press, Collegeville, Minneapolis, MN.

Chimombo, J., 2009, 'Changing patterns of access to basic education in Malawi: A story of a mixed bag?', Comparative Education 45(2), 297-312. https://doi.org/ 10.1080/03050060902921003

Chisholm, H., 1911, 'Panegyric', in H. Chrisholm (ed.), Encyclopaedia Britannica pp. 676-677, Cambridge University Press, Cambridge.

Coleman, R., 2017, 'The Lukan beatitudes (Luke 6.20-26) in the canonical choir: A "Test Case" for John Christopher Thomas' hermeneutical proposal', Journal of Pentecostal Theology 26(1), 48-67. https://doi.org/10.1163/17455251-02601006

Danker, F., Bauer, W., Arndt, W. \& Gingrich, F.W. (eds.), 2000, Greek-English lexicon of the New Testament and other early Christian literature, University of Chicago Press, Chicago, IL.

De Bouvre, S., 2012, 'Greek festivals and the ritual process', in J.R. Brandt \& J.W. Iddeng (eds.), Greek and Roman festivals: Content, meaning, and practice, pp. 253-293, Oxford University Press, Oxford.

Dreyer, J.S., 2015, 'Ubuntu', International Journal of Practical Theology 19(1), 190-209. https://doi.org/10.1515/ijpt-2015-0022

Elliott, J.H., 1991, 'Household and meals vs. temple purity replication patterns in Luke-Acts', Biblical Theology Bulletin 21(3), 102-108. https://doi.org/10.1177/ 014610799102100304

Esler, P., 1987, Community and Gospel in Luke-Acts: The social and political motivations of Lucan theology, Cambridge University Press, Cambridge.

Fitzmeyer, J., 1981, The Gospel according to Luke, Double Day, New York, NY.

Fox, R., 2005, The classical world: An epic history of Greece and Rome, Penguin, New York, NY

Gallia, A., 2012, 'A book review of Paul Roche's Pliny's praise, the Panegyricus in the Roman world', Classical Review 44.

Hanson, K.C., 1996, 'How honourable! How shameful! A cultural analysis of Matthew's makarisms and reproaches', Semeia 68, 81-111.

Hornblower, S. \& Spawforth, A., 1996, The Oxford classical dictionary, Oxford University Press, Oxford.

International Monetary Fund, 2019, 'World economic outlook database April', viewed 20 December 2019, from https://www.imf.org/external/pubs/ft/weo/2019/01/ weodata/index.aspx

Jehne, M., 2011, 'Blaming the people in front of the people', in C. Smith \& R. Covino (eds.), Praise and blame in Roman republican rhetoric, pp. 111-125, Classica Press of Wales, Swansea.

Kennedy, G., 1984, New Testament interpretation through rhetorical criticism, University of North Carolina Press, Chapel Hill, NC.

Kurke, L., 1991, The traffic in praise: Pindar and the poetics of social economy, Cornel University, London.

Liddell, H.G., Scott, R. \& Jones, H.S., 2020, Perseus programme, viewed 10 April 2020 from http://www.perseus.tufts.edu/hopper/morph? =greek\#lexicon.
Loba-Mkole, J., 2008, 'Rise of intercultural biblical exegesis in Africa', HTS Teologiese Studies/Theological Studies 64(3), 1347-1364. https://doi.org/10.4102/hts. v64i3.77

Malina, J.B., 2001, The New Testament world: Insights from cultural anthropology Westminster John Knox Press, Louisville, KY.

Mbengu, D.N., 2011, 'Contextualising biblical exegesis: What is the African biblical hermeneutic approach', HTS Teologiese Studies/Theological Studies 69(1), 1-10.

Miller, P., 2018, 'In the shadow of praise: Epinician losers and epinician poetics', Bulletin of the Institute of Classical Studies 61(1), 21-41. https://doi.org/10.1111/20415370.12068

Morwood, J., 1994, Oxford Latin, Oxford University Press, Oxford.

Moxnes, H., 2003, Putting Jesus in his place, Westminster John Knox Press, Louisville, KY.

Musopole, A., 2018, 'uMunthu and the decolonising of education in Malawi', Journa of Development and Communication Studies 5(2), 1-21. https://doi.org/10.4314/ jdcs.v5i2.1

Mussa, R. \& Masanjala, W.H., 2015, 'A dangerous divide: The state of inequality in Malawi: Oxfam Report', Oxfam, viewed 20 March 2020, from https://www-cdn. oxfam.org/s3fs-public/file_attachments/rr-inequality.

National Statistics Office, 2008, 'Malawi national census report', National Statistics Office, viewed 20 May 2019, from http://www.nsomalawi.mw/images/stories/data on line/demography/census_2008/Main\%20Report/Census\%20Main\%20Report.pdf.

Neyrey, J.H., 1998, Honour and shame in Matthew, Westminster John Knox Press, Louisville, KY.

Nightingale, A.W., 1995, Genres in dialogue, Plato and the construction of philosophy, Cambridge University Press, Cambridge.

Oakman, D.E., 2014, Jesus, debt and the Lord's Prayer, Cascade Books, Nashville, TN.

Pernot, L., 2014, Epideictic rhetoric: Questioning the stakes of ancient praise, University of Texas Press, Austin, TX.

Pomeroy, S.B., Burstein, S.M., Donlan, W. \& Roberts, J.T., 1999, Ancient Greece: A political, social, and cultural history, Oxford University Press, Oxford.

Roche, P., 2011, 'Pliny's thinking: An introduction to the Panegyricus', in P. Roche (ed.) Pliny's praise: Panegyricus in the Greco-Roman world, pp. 1-28, Cambridge University Press, Cambridge.

Sheard, C.M., 1996, 'The public value of epideictic rhetoric', College English 58(7), 765-794. https://doi.org/10.2307/378414

Steinbock, B., 2011, 'A lesson in patriotism: Lycurgus against Leocrates, the ideology of the Ephebeia and Athenian social memory', Classical Antiquity 30(2), 279-317.

Sullivan, D., 1999, 'Identification and dissociation in rhetorical exposé: An analysis of St Irenaeus against heresy', Rhetoric Society Quarterly 29(1), 49-76. https://doi. org/10.1080/02773949909391137

Tannehill, R.,1996, Luke, Abingdon Press, Nashville, TN.

Topel, L., 2001, Children of a compassionate God, Liturgical Press, Collegeville, Minneapolis, MN.

United Nations Children's Fund, 2019, 'Malawi', UNICEF, viewed 28 March 2020, from https://www.unicef.org/malawi/sites/unicef.org.malawi/files/2020-07/ UNICEF\%20Malawi\%202019\%20Annual\%20Report.pdf.

Van Eck, E., 2006, 'The word is life: African theology as biblical and contextual theology', HTS Teologiese Studies/Theological Studies 62(2), 679-701. https://doi. org/10.4102/hts.v62i2.359

Van Eck, E., 2009, 'A prophet of old: Jesus the "public theologian"', HTS Teologiese Studies/Theological Studies 66(1), Art. \#771, 10 pages. https://doi.org/10.4102/ hts.v66i1.771

Verheyden, J., 1999, 'Unity of Luke-Acts', HTS Teologiese Studies/Theological Studies 55(4), 964-979. https://doi.org/10.4102/hts.v55i4.1657

Villadsen, L.S., 2008, 'Speaking on behalf of others: Rhetorical agency and epideictic functions in official apologies', Rhetoric Society Quarterly 38(1), 25-45. https:// doi.org/10.1080/02773940701779769

Zere, E., Moeti, M., Kirigia, J., Mwase, T. \& Kataika, E., 2007, 'Equity in health and healthcare in Malawi: Analysis of trends', BMC Public Health 7(78), 1-13. https:// doi.org/10.1186/1471-2458-7-78vww 